\title{
PROBLEMS EXPERIENCED WITH THE TEACHING OF ARABIC TO LEARNERS IN MUSLIM PRIVATE SCHOOLS IN SOUTH AFRICA AND BOTSWANA
}

\author{
MA Mall, Al-Nur School, Gaborone \& MM Nieman, Unisa
}

This article discusses a number of problems that are unique to the teaching of Arabic in private schools in South Africa and Botswana. Specific attention is given to aspects of teaching that mean that learners are unable to reach a level of communicative competence in Arabic or to understand the Koran (despite the fact that this is an important goal in teaching Arabic). An investigation conducted with the aid of questionnaires revealed that Arabic teachers do not have confidence in their own language proficiency or their ability to speak Arabic fluently. It seems that teaching is largely based on the Grammar-Translation method: learning of new vocabulary and grammar rules. It also appears that most teachers believe that learners study Arabic for religious purposes (to be able to read the Koran) so they are not so much interested in developing communicative skills as in extending their vocabulary and knowledge of grammar so they will be able to understand the formal language of the Koran.

In hierdie artikel word 'n aantal probleme wat eie is aan die onderrig van Arabies in Moslem privaatskole in Suid-Afrika en Botswana bespreek. Daar word spesifiek aandag gegee aan onderrigaspekte wat instrumenteel is tot die leerders se onvermoë om 'n mate van kommunikatiewe bevoegdheid in Arabies te bereik en om die Koran met begrip te lees (ten spyte daarvan dat dit ' $n$ belangrike doelstelling met die onderrig van Arabies is). Uit 'n ondersoek wat met behulp van vraelyste gedoen is, blyk dit dat die meerderheid Arabiese onderwysers nie vertroue het in hul eie taalvaardigheid en hul vermoë om vlot in Arabies te kommunikeer nie. Daar word ook aangedui dat onderrig hoofsaaklik gebaseer is op die grammatika-vertaalmetode, die aanleer van nuwe woordeskat en die leer van grammatikareëls. Dit blyk ook dat die meerderheid onderwysers van mening is dat leerders Arabies bestudeer vir religieuse doeleindes (om die Koran te kan lees) en daarom nie soseer ingestel is op die ontwikkeling van kommunikatiewe vaardighede nie, maar eerder op die nodige woordeskatuitbereiding en grammatika wat hulle in staat sal stel om die formele taalgebruik van die Koran te kan verstaan.

\section{INTRODUCTION}

Second and foreign language teaching is a common phenomenon, and although much research has been conducted in this field, many areas still require attention. In this article, one such area, namely that of teaching Arabic as an additional (second or foreign) language will be addressed. The focus will be on problems in the present Arabic teaching situation in South Africa and Botswana.

Arabic is a language in spoken by one of the largest groups of people in the world. According to Mohammed (1997:xiii), it is the official language of more than 200 million people and the 
language of religious practice of more than one billion Muslims. It has become an international language primarily because of the universal nature of Islam. Arabic has successfully retained its classical and standard nature as embodied in the Qur'an, chiefly because of the nature of the language and the sustained attempts made by Muslims and Arabic grammarians to prevent it from being corrupted by different dialects and the effects of colonisation (Al-Attas 1985:162). Although there are several English versions of the Qur'an, none is really satisfactory. It is thus expected of to learn Arabic (Bowker 1995:10).

In Africa, the total number of Arabic speakers accounts for one-third of Africa's inhabitants (Majid 1987:1). Since Arabic is inextricably linked to Islam, it has been taught in South Africa since the advent of the first Muslims in 1658. Although Muslims first arrived in Botswana in 1872, interest in teaching Arabic developed much later (1979), mainly because of the country's link with North African countries, such as Libya. The impetus for learning the language took on a new dimension in South Africa, particularly since the abolishment of apartheid in 1994. People began to realise that Arabic is an essential tool towards establishing international links with Africa and the Middle East in particular. Thus, Arabic is not associated only with religion, but also with politics and economics. The purpose of teaching Arabic is therefore dual in nature. According to Dadoo (1990:81), there are two categories of objectives of Arabic learning: religious and mundane. He states that for Muslims, religious reasons are paramount, while for non-Muslims economic opportunity motivates the learning of the language.

\section{BACKGROUND TO THE PROBLEM}

Although the majority of the learners studying Arabic as an additional language hear the language in the form of prayer and recitation from birth, few achieve a satisfactory level of communicative competence. Pupils are in daily contact with the language through the practise of religion - they are taught to perform ritualistic prayer in Arabic, and are expected to recite from the Qur'an fluently by the age of eight - yet they are unable to communicate effectively in Arabic or even understand what they hear (Majid 1987:3). Learners have been taught to 'read' Arabic in a parrot-like manner. Most of them are able to 'read' from the text of the Qur'an (which is in Arabic) fluently, but with no understanding or comprehension (Allen in Mohamed 1997:9; Mujahid 2002:2).

This problem is also acknowledged by Bowker (1995:138). He, however, states that although understanding is important, there is a virtue in Islam in reciting the Qur'an for its own sake; there can be a value in it quite apart from issues of understanding (Bowker 1995:140). This point of view is in contrast with current language teaching practices where the emphasis is on understanding and comprehension. Bowker (1995:141-142) explains that the First World Conference on Muslim Education, which was held in 1977, emphasised the Arabic language as the key to the understanding of the divine revelation presented in the Qur'an and Sunna, and the teaching of Arabic as compulsory.

The notion that the Arabic language is the key to the understanding of the Qur'an and that there is a virtue in reciting the Qur'an for its own sake, relates to the issue of Islamization. This concept was defined for the first time by Al-Attas (1985:xi) in 1985. Islamization (the word was formed analogous to Westernization) is the liberation of man from magical, mythological, animistic, national-cultural tradition, and then from secular control over his reason and his language (Al-Attas 1985:41; 1993:44). The Arabic language itself (and all 
other non-Arabic languages of Muslim peoples) have not been exempted from the process of Islamization. This implies that Arabic, as the language of the Qur'an should accurately reflect the original message with no room for '... learned guess or conjecture, no room for interpretation based upon subjective readings, or understandings based merely upon the idea of historical relativism as if semantic change had occurred in the conceptual structures of the words and terms that make up the vocabulary of the sacred text'. Al-Attas $(1985: 198)$ proposes the exertion of constant vigilance in detecting erroneous language use, which can create general confusion and error in the understanding of Islam and of its world-view. He further argues for the desecularisation of the Arabic language (Al-Attas 1985:161; 188-189; 193-197). This argument is in contrast with the notion of communicative competence in foreign language teaching, where the focus is on the learners' ability to use the language in different contexts for sending and receiving appropriate messages.

According to Allen (Mohamed 1997:9), the texts used in Arabic language teaching have been successful in developing reading, but do not constitute genuine reading ability, as they do not develop comprehension. Most learners are thus 'barking at print' when they read Arabic, in other words, they read aloud and may read very fluently, but they do not understand the meaning of the written message (Wessels \& Van den Berg 1998:201). Although the current focus of teaching Arabic is on the acquisition of receptive skills (reading and understanding), these skills are not being acquired effectively.

The majority of individuals who have acquired competence in Arabic as an additional language, have not learnt it through the schooling system. Some of these individuals have acquired Arabic in foreign countries, whilst others have learnt it through Muslim Seminaries in South Africa (see also Mohamed 1997:144). This suggests that the teaching methodology used in schools may be the reason for this dilemma. Mohammed (1997:13) states that despite the efforts to change to communicative Arabic, examinations at schools are still based on the grammar-translation method and it seems that teachers prepare their learners for this type of assessment.

\section{FACTORS THAT PROMPTED THE RESEARCH}

As a teachers of languages (Arabic and English) in various Muslim schools in South Africa and Botswana, we have noticed this lack of communicative competence and low proficiency levels in all four language skills over many years and has always been concerned about this phenomenon. There is reason for concern, even though it is realised that additional language competence does not equate with native speaker competence.

Many teachers of Arabic are aware of the existing problem, and numerous discussions at teachers' seminars, workshops and professional development programmes have taken place over the years, but either the problem has not been seriously tackled or plans of action have not been implemented. One such example is that of a workshop held in KwaZulu-Natal in 1984. At this workshop, a paper was presented on Teaching Arabic - Thematic Approach, in which it was stated, '...since the inception of Arabic in Secondary Schools, inadequate methods of teaching the language has resulted in pupils dropping the subject at the Senior Secondary Phase, ... with this in mind we would like to arouse greater interest, love and appreciation for the language by introducing the thematic approach' (Ebrahim 1984:1). 
Yet another attempt aimed at improving Arabic teaching methodology was made during an orientation course held for Arabic teachers at Stanger Madressa School in KwaZulu-Natal in 1985. The argument was mooted that '(Since) Arabic is a living language - a language of political, social, cultural and scientific expression - parroting of syntax and laws of grammar are no more useful, maximum benefits may be derived through the use of audio-visual and other scientific teaching aids' (Kathrada 1985:1). In a paper read by Ebrahim (1986:12-3), it was suggested that the teaching approach could be a problem:

Students, who have received several years of formal Arabic teaching, frequently remain deficient in the ability to actually use the language, and to understand its use, in normal communication, whether in the spoken or written mode. Since it seems that the problem lies in the approach of teaching Arabic, what is needed is a shift of the focus of attention from the grammatical to the communicative properties of the language.

The Association of Muslim Schools (AMS) has also conducted several seminars for the same purpose. One such example is a Programme for the Development of Arabic Syllabus and Textbooks which was co-ordinated by Irshad Amod in March 1996 at the following affiliated schools: Nurul Islam, Lenasia; Johannesburg Muslim School, Johannesburg; Pretoria Muslim School, Laudium. At this seminar it was once again emphasised that an alternative approach to the teaching of Arabic is of the utmost importance.

Despite these and numerous other discussions, the teaching methods have not changed significantly and the problem of neither achieving communicative competence in Arabic nor being able to read the Qur'an with comprehension still remains unresolved. Although the problem is widely acknowledged (Mohammed 1997:13; Nuruddin 1992:42; Mujahid 2002:3; Emerick 2002:3), very little scientific research has been conducted in this area. Thus, the researcher hopes that the research reported on in this article may highlight problem areas clearly and scientifically and provide a starting point for further research and eventual change.

\section{RESEARCH QUESTIONS AND DEMARCATION}

There appears to be general agreement that there are problems with the teaching and learning of Arabic as a second or foreign language. The areas of concern seem to revolve around the teaching methodology used in schools, teachers' proficiency in Arabic and the purpose of teaching Arabic as an additional language (secular or mundane) (Allen 1990; Dawood, Amod \& Kader 1996; Mohammed 1997 and Ebrahim 1986). The basic questions the research thus attempted to answer were:

1. How is Arabic taught in private Muslim schools in South Africa and Botswana?

2. How do teachers' perceptions of the aims of teaching Arabic, their own fluency in the language and their beliefs about second/foreign language teaching impact on their teaching practice?

Since the researche involved had been an Arabic teacher in South Africa and Botswana, it was decided that these two countries should be used for this study. The decision to focus on Muslim private schools was made because of the increasing number of such schools and because they provide an attractive alternative for the Muslim learner. In addition, the 
researcher, being involved in a Muslim private school, feels intuitively attracted to the problems they face. Moreover, Arabic is an essential part of the curriculum in most Muslim private schools, whilst this is not the case in government schools.

\section{RESEARCH DESIGN}

\section{Research instrument}

A questionnaire, in which both open-ended and close-ended questions were used, was compiled for the purpose of this study. Four types of close-ended questions were included. The first was a checklist used to obtain information related to demographic details. The second type of question with a closed response was asked in the form of the Lickert type scale. A four-point scale was mainly used. These questions were used to determine Arabic teachers' opinions on the purpose of Arabic teaching, how Arabic should be taught and how Arabic is actually being taught at present. Another type of close-ended question used was the semantic differential scale. This was used to determine the extent to which learners in the Arabic class could communicate with each other in Arabic and how committed they were to do so. Rank-order types of questions were also used. In this case, teachers were expected to rank given teaching methodologies from least successful to most successful. Open-ended questions were finally included to determine what teachers perceive as the major problem areas in teaching Arabic in South Africa and Botswana.

\section{Population and sampling}

Since there are currently only 60 Muslim private schools in Botswana and South Africa, it was initially decided to include all 60 schools in this study. After preliminary investigations it was discovered that six of these schools did not include Arabic in their curriculum, therefore they were excluded from the study. A total of 54 schools, 33 (61\%) of which responded, were thus involved in the investigation. Through personal and telephonic communication the researcher found that teachers who did not respond felt unhappy with answering the questionnaire. They claimed that there were numerous outside forces that were responsible for the problems associated with teaching Arabic. They were reluctant to have teaching methods and their inability to communicate in the language identified as important contributory factors and therefore refused to take part in the investigation.

\section{Statistical techniques}

An item analysis was done for each of the items in the questionnaire. Responses on closeended items were put into frequency tables, while open-ended responses were qualitatively analysed by interpreting the meaning and significance of the information given. In this article, only a number of items will be reported on, namely those related to the teachers' language proficiency, the aim of teaching Arabic, the teaching methods applied by teachers, examinations and recommendations made by teachers. 


\section{DATA ANALYSIS}

\section{Teachers' language abilities}

Several of the items in the questionnaire related to the teacher's profile of his/her own language abilities. The key variables in this section of the questionnaire were the teacher's first language, preferred language of communication and the rating of his/her ability in each of the four language skills. Although only one respondent $(3.0 \%)$ indicated Arabic as his/her first language, four of the respondents (12.1\%) indicated Arabic as their preferred language of communication (Mall 2001:106-107). However, the last variable in this cluster, i.e. the teachers' rating of their own abilities in each of the four language skills, is particularly important for this study and must therefore receive special attention.

Table 1: Teachers' perceived ability in each of the language skills

\begin{tabular}{|l|r|r|r|r|r|c|r|r|}
\hline & \multicolumn{2}{|c|}{ Speaking } & \multicolumn{2}{c|}{$\begin{array}{c}\text { Reading with } \\
\text { comprehension }\end{array}$} & \multicolumn{2}{c|}{$\begin{array}{c}\text { Listening with } \\
\text { comprehension }\end{array}$} & \multicolumn{2}{c|}{ Writing } \\
\hline Rating & $\begin{array}{c}\text { Fre- } \\
\text { quency }\end{array}$ & $\%$ & $\begin{array}{c}\text { Fre- } \\
\text { quency }\end{array}$ & $\%$ & $\begin{array}{c}\text { Fre- } \\
\text { quency }\end{array}$ & $\%$ & $\begin{array}{c}\text { Fre- } \\
\text { quency }\end{array}$ & $\%$ \\
\hline Very good & 10 & 30.3 & 17 & 51.5 & 12 & 36.4 & 12 & 36.4 \\
\hline Good & 7 & 21.2 & 6 & 16.2 & 6 & 18.2 & 4 & 12.1 \\
\hline Average & 7 & 21.2 & 7 & 21.2 & 10 & 30.3 & 10 & 30.3 \\
\hline Poor & 8 & 24.2 & 2 & 6.1 & 4 & 12.1 & 6 & 18.2 \\
\hline Very poor & 1 & 3.0 & 1 & 3.0 & 1 & 3.0 & 1 & 3.0 \\
\hline Total & 33 & 100.0 & 33 & 100.0 & 33 & 100.0 & 33 & 100.0 \\
\hline
\end{tabular}

These are extremely significant statistics, as they reflect that a large proportion of Arabic teachers are not confident of their own proficiency in Arabic. An alarmingly high percentage of respondents rated their competence in each of the four language skills as either average or poor, while one respondent rated his/her abilities throughout as very poor. Of the respondents, $45.4 \%$ rated their own ability to speak Arabic between average to poor, $27.3 \%$ were average to poor readers of Arabic, $48.5 \%$ rated their ability to understand spoken Arabic as being between average and poor, while the same number of respondents regarded their ability to communicate through writing as either average or poor. It seems that reading in Arabic is the best-developed language skill among the respondents.

The fact that teachers regard themselves as better readers than speakers of Arabic, is a cause for concern, as second and foreign language teachers are required to speak a great deal since the only exposure to the target language, in this case Arabic, is the teacher's speech. If the teachers are not fluent in the language they teach, it is unlikely that the learners will become fluent or confident speakers and the only exposure to the target language, to spoken Arabic that learners get is mostly (especially in the case of foreign language learning) the teacher's speech.

Nurruddin (1992:40) takes a stronger view. He emphasises that every teacher coaxing children to speak Arabic should be able to speak Arabic fluently, correctly, enjoyably and with great ease. At the same time he, however, points out that there are few persons locally 
who have mastered both conversational and grammatical approaches. Thomas (1987:36) also stresses the importance of language competence. According to Thomas (1987:36), second language teachers should, first of all, have language competence. They should, therefore, have a thorough knowledge and awareness of the system (phonology, syntax, lexicon, etc.) of the target language and of using the language during communication (e.g. notion and function). It is essential for the teacher himself/herself to be a competent user of the language. In the second place, the teachers should have the competence or skills to teach the language.

\section{Teaching Arabic}

Several of the questions in the questionnaire focused on the actual teaching of Arabic. The key variables of these questions were related to the teachers' perceptions of why learners choose Arabic as a subject, the time spent on various language activities such as translating to and from Arabic, listening to and speaking in Arabic and learning grammar rules and vocabulary. A number of questions also related to teachers' perceptions of how Arabic should be taught.

Table 2: Reasons for learning Arabic as a second/foreign language

\begin{tabular}{|l|c|c|}
\hline & Frequency & \% \\
\hline Religious reasons & 24 & 72.7 \\
\hline Other reasons & 9 & 27.3 \\
\hline Total & 33 & 100.0 \\
\hline
\end{tabular}

According to $72.7 \%$ of the respondents, learners choose Arabic for religious reasons, while $27.3 \%$ indicated that they choose it for other reasons. It can be assumed that if teachers think that learners learn Arabic for religious purposes (in other words to enable them to read Allah's revelation in its original language and to understand his message), they would emphasise communicative competence less and understanding the grammar and vocabulary of the language more. This assumption provides a possible explanation for the observation made in Table 1, namely that reading in Arabic is the best-developed language skill among the respondents. The ensuing data obtained from the questionnaires actually confirms that communicative competence in Arabic is not a priority when teaching Arabic and that the learning of grammar and new vocabulary is emphasised. 
Table 3: Time spent by learners on various language learning activities

\begin{tabular}{|l|r|r|r|r|r|r|r|r|}
\hline & \multicolumn{2}{|c|}{$\begin{array}{c}\text { Translating to } \\
\text { and from Arabic }\end{array}$} & \multicolumn{2}{c|}{$\begin{array}{c}\text { Listening to and } \\
\text { speaking Arabic }\end{array}$} & \multicolumn{2}{c|}{$\begin{array}{c}\text { Learning } \\
\text { grammar rules }\end{array}$} & \multicolumn{2}{c|}{$\begin{array}{c}\text { Learning new } \\
\text { vocabulary }\end{array}$} \\
\hline & $\begin{array}{c}\text { Fre- } \\
\text { quenc } \\
\text { y }\end{array}$ & $\%$ & $\begin{array}{c}\text { Fre- } \\
\text { quency }\end{array}$ & \multicolumn{1}{c|}{$\begin{array}{c}\text { Fre- } \\
\text { quency }\end{array}$} & $\begin{array}{c}\text { Fre- } \\
\text { quenc } \\
\text { y }\end{array}$ & $\%$ \\
\hline $\begin{array}{l}\text { Very little } \\
\text { time }\end{array}$ & 6 & 18.2 & 21 & 63.6 & 8 & 24.2 & 3 & 9.1 \\
\hline A little time & 6 & 18.2 & 5 & 15.2 & 8 & 24.2 & 7 & 21.2 \\
\hline A lot of time & 11 & 33.3 & 6 & 18.2 & 14 & 42.4 & 13 & 39.4 \\
\hline $\begin{array}{l}\text { Most of the } \\
\text { time }\end{array}$ & 8 & 24.2 & 0 & 0 & 3 & 9.1 & 10 & 30.3 \\
\hline $\begin{array}{l}\text { Missing } \\
\text { system }\end{array}$ & 2 & 6.1 & 1 & 3.0 & 0 & 0 & 0 & 0 \\
\hline Total & 33 & 100.0 & 33 & 100.0 & 33 & 100.0 & 33 & 100.0 \\
\hline
\end{tabular}

The results in Table 3 suggest that teachers rely strongly on the grammar-translation method when teaching Arabic. The largest proportion (57.5\% in total) of the respondents indicated that the learners they taught spent either a lot or most of the time translating to and from Arabic. The fact is that $42.4 \%$ of the respondents/learners spent a lot of their time learning grammar rules, while $9.1 \%$ spent most of their time on learning grammar rules is further evidence of the grammar translation emphasis. Learning new vocabulary also takes up a lot of time. According to $39.4 \%$ of the respondents learners spent a lot of their time learning new vocabulary, while $30.3 \%$ of the respondents' learners spent most of their time on this activity. A reason for concern is the indication by the majority $(63.6 \%)$ of respondents that their learners spent very little of their time listening to and speaking Arabic. This correlates with the data in Table 1, where teachers revealed their own lack of competence in speaking Arabic. It could be that teachers project their own inabilities to the learners. As they themselves do not feel comfortable speaking Arabic, they also do not provide sufficient time for their learners to do so. The great amount of time spent on translating, learning new vocabulary and grammar rules, could possibly be ascribed to the teachers' notion that learners learn Arabic mostly for religious reasons (refer to Table 2), however, it could also be due to the poor quality of Arabic textbooks. After an analysis of various textbooks, Mall (2001:74) came to the conclusion that although attempts were made to produce more meaningful textbooks in the eighties and nineties, '... they still remain essentially grammar text books, with a few conversations and dialogues. They continue to encourage the grammar-translation method through their numerous exercises and vocabulary lists at the end of each chapter. Emerick (2002:3) confirms this: The Arabic books are almost always complicated, boring and rely on endless drills of copying. Vocabulary lists are long... Younes (1990:107) also cites textbooks as one of the reasons for low proficiency levels in Arabic. Examinations also contribute to this approach. According to Mohammed (1997:13) examinations at schools and universities are still based on the grammar-translation method. It seems that teachers prepare their learners for this type of assessment.

Questions on teachers' perceptions on how Arabic should be taught were included to determine whether respondents know what is important and should be done even if they do not teach accordingly. These questions revealed the following: 
Table 4: Teachers' perceptions on the importance of performing various language learning activities

\begin{tabular}{|c|c|c|c|c|c|c|c|c|c|c|}
\hline & \multicolumn{2}{|c|}{$\begin{array}{l}\text { Translating to } \\
\text { and from } \\
\text { Arabic }\end{array}$} & \multicolumn{2}{|c|}{$\begin{array}{l}\text { The importance } \\
\text { of hearing } \\
\text { authentic } \\
\text { Arabic being } \\
\text { spoken }\end{array}$} & \multicolumn{2}{|c|}{$\begin{array}{l}\text { The importance } \\
\text { of learners } \\
\text { communicating } \\
\text { with each other } \\
\text { and the teacher } \\
\text { in Arabic }\end{array}$} & \multicolumn{2}{|c|}{$\begin{array}{l}\text { The importance } \\
\text { of learning } \\
\text { grammar rules }\end{array}$} & \multicolumn{2}{|c|}{$\begin{array}{l}\text { The importance } \\
\text { of learning new } \\
\text { vocabulary }\end{array}$} \\
\hline & $\begin{array}{c}\text { Fre- } \\
\text { quency }\end{array}$ & $\%$ & $\begin{array}{c}\text { Fre- } \\
\text { quency }\end{array}$ & $\%$ & $\begin{array}{c}\text { Fre- } \\
\text { quency }\end{array}$ & $\%$ & $\begin{array}{c}\text { Fre- } \\
\text { quency }\end{array}$ & $\%$ & $\begin{array}{c}\text { Fre- } \\
\text { quency }\end{array}$ & $\%$ \\
\hline Important & 3 & 9.1 & 6 & 18.2 & 10 & 30.3 & 8 & 24.2 & 7 & 21.2 \\
\hline $\begin{array}{l}\text { Very } \\
\text { important }\end{array}$ & 16 & 48.5 & 15 & 45.6 & 12 & 36.4 & 7 & 21.2 & 11 & 33.3 \\
\hline $\begin{array}{l}\text { Of the } \\
\text { utmost } \\
\text { importance }\end{array}$ & 14 & 32.4 & 12 & 36.4 & 11 & 33.3 & 18 & 54.5 & 15 & 45.5 \\
\hline TOTAL & 33 & 100.0 & 33 & 100.0 & 33 & 100.0 & 33 & 100.0 & 33 & 100.0 \\
\hline
\end{tabular}

The fact that more than $90 \%$ of the respondents indicated that they regarded translating to and from Arabic as very important or of the utmost importance, confirms the observation that teachers teach Arabic to a greater extent by making use of the grammar-translation method. Although they do acknowledge the importance of hearing authentic Arabic being spoken (45.6\% rated it as important and $36.4 \%$ rated it as of the utmost importance), they evidently do not regard verbal communication with each other and with the teacher as being as important as learning grammar rules and adding to their vocabulary. This can be seen from the fact that $69.7 \%$ of the respondents regarded verbal communication with each other and the teacher as either very important or of the utmost importance, compared with $75.7 \%$ who rated the learning of grammar rules as very important or of the utmost importance and the $78.8 \%$ who rated learning new vocabulary as very important or of the utmost importance.

The findings as set out in Table 4 once again confirm the notion the teachers' goal in teaching of Arabic is not to achieve communicative competence with learners, but rather to enable learners to acquire the necessary vocabulary and grammar rules, probably in order to perform religious practices in Arabic. A startling factor that should be considered is that although the majority of respondents are of the opinion that learners study Arabic for the sole purpose of reading and understanding the Qur'an (Table 3), respondents fail to achieve this with the learners, as can be seen from Tables 5 and 6 .

Table 5: Learners' ability to read the Qur'an fluently

\begin{tabular}{|l|r|c|}
\hline $\begin{array}{l}\text { Are learners able to read the Qu'ran } \\
\text { fluently? }\end{array}$ & Frequency & Percentage \\
\hline Yes & 26 & 78.8 \\
\hline No & 5 & 15.2 \\
\hline Missing system & 2 & 6.1 \\
\hline Total & 33 & 100.0 \\
\hline
\end{tabular}


Table 6: Learners' ability to understand the Qur'an

\begin{tabular}{|l|c|c|}
\hline $\begin{array}{l}\text { Learners' level of comprehension when reading } \\
\text { the Qur'an }\end{array}$ & Frequency & Percentage \\
\hline full comprehension & 0 & 0.0 \\
\hline partial comprehension & 4 & 12.1 \\
\hline little comprehension & 17 & 51.5 \\
\hline no comprehension & 8 & 24.2 \\
\hline Total & 29 & 87.9 \\
\hline missing system & 4 & 12.1 \\
\hline total & 33 & 100.0 \\
\hline
\end{tabular}

According to the respondents, the majority of learners $(78.8 \%)$ are able to read the Qur'an fluently, but not one of the children can read it with full comprehension, while a mere $12.1 \%$ can read with partial comprehension. The rest of the learners either read with little comprehension $(51.5 \%)$ or no comprehension at all $(24.2 \%)$. These statistics confirm the information found in the literature that the ability to read fluently does not necessarily imply comprehension (refer to sect. 2.1). It is thus clear that learners can neither use Arabic to communicate nor to read and understand the Qur'an.

Respondents were also asked whether they were of the opinion that Arabic should be taught through the medium of Arabic. They were almost equally divided in their response. $48.5 \%$ disagreed, while 51.5\% agreed that Arabic should be taught through the medium of Arabic (Mall 2001:131). The reason for the large percentage of respondents who feel that Arabic should not be taught through the medium of Arabic could possibly be that only $30.3 \%$ (refer to Table 1) are able to speak the language well and that the majority of teachers are illequipped to teach through the medium of Arabic. This is problematic. Younes $(1990: 107)$ emphasises that if teachers do not speak Arabic in class they do not reinforce what learners learn form the book.

\section{Responses to the open questions}

The last two questions in the questionnaire were open-ended questions. These allowed respondents to provide any additional information about the teaching of Arabic and make relevant suggestions.

The majority of the respondents expressed their need for a syllabus that catered for the needs of the Southern African learner. They suggested that more attention should be paid to the oral component, to facilitate acquisition of the speaking skill. Some of the respondents indicated that they would like to see themes that are more practical and would also welcome more conversation about the environment to being introduced in Arabic lessons to make the language a living language. Respondents indicated that since a large proportion of learners studied Arabic for religious reasons, it is imperative that learners should be familiar with Qur'anic vocabulary. These comments made by the respondents correlate with the methods used in teaching Arabic (i.e. large amounts of time spent on translating to and from Arabic, learning new vocabulary and grammar rules, etc.). 
Many respondents highlighted the need to train teachers in the communicative approach, as numerous teachers have studied the language through the grammar-translation or audiolingual method and are therefore lacking the expertise to teach according to the latest trends and techniques. They requested seminars, workshops and even refresher courses, specifically directed at developing the Arabic teachers' speaking skills, so that they would be more comfortable speaking the language with their learners. Respondents also requested that universities, Muslim seminaries and other higher education institutions at which Arabic is currently taught, seriously revise their syllabi to ensure that students adequately acquire all four language skills. They also suggested that Arabic teachers should be adequately trained in the practical teaching of the language as a second or foreign language (second language teaching methodology).

A few respondents indicated that until Arabic is taught through the medium of Arabic, there would always be problems concerning the acquisition of the speaking skill. Individual respondents indicated the need for locally produced resources to teach the language. They felt that some of the textbooks being used were designed for first language speakers, while others were based totally on grammar-translation. Textbooks, accompanied by audio-visual aids would assist teachers to develop learners comprehension and speaking abilities.

\section{SUMMARY AND CONCLUSION}

The results of the investigation into the problems related to teaching of Arabic in Muslim private schools reveal that there are a significant number of Arabic teachers who are not fluent speakers of the language. This is possibly the reason why they do not teach through the medium of Arabic or spend a significant amount of time promoting the acquisition of speaking skills. Despite their awareness of the importance of nurturing communicative skills in Arabic, more than half of the teachers still firmly believe that learning and applying grammar rules and translating to and from Arabic, are crucial. This could also account for the fact that learners spend more time translating to and from Arabic, learning grammar rules and new vocabulary than listening to and speaking Arabic. Consequently, the examinations are largely grammar-based and very little attention is given to assessing learners' ability to communicate orally.

A serious problem revealed in this study is the dual purpose with which Arabic is taught. There is a widely accepted notion amongst teachers that learners learn Arabic for religious purposes. In pursuit of this goal, they strive to enable learners to read and understand the Qur'an. In the process the achievement of communicative competence becomes a side issue. The predicament is that although teachers believe that the largest proportion of learners study Arabic for religious reasons, their learners are able to read the Qu'ran fluently, but they do so without understanding what they are reading. If teachers are of the opinion that there is a virtue in Islam in reciting the Qur'an for its own sake (see page 43) it can be expected that they will not regard this as problematic. If a clear distinction between the teaching of Arabic for religious purposes (the Islamization and desecularisation of the Arabic language) and for communicative purposes is not made, the problem will continue. If students' goal is to read and understand the Qu'ran, they should be taught Classical Arabic; if their goal is to achieve communicative competence in the language, they should be helped to do so. 
From an analysis of the open questions, it became clear that teachers are aware of the problems and of their own shortcomings, but that they need help to rectify the situation. Consequently, there is an urgent need for higher education institutions where Arabic is taught and where teacher training is taking place to reconsider the rationale for Arabic teaching. The primary focus should be on achieving communicative competence, in other words the ability to adapt to different contexts and use the language appropriately for receiving and sending messages. As such this differs from the artificial non-communicative manipulation of language which is so characteristic of many additional language programmes at higher education institutions. In addition, in-service training should be done on a regular basis to ensure that effective and professional methods of language teaching find their way into the classroom. It seems that the syllabi and textbooks used in schools are also a source of concern; therefore revision of these two elements is of the utmost importance.

\section{REFERENCES}

ALLEN, R. 1990. Proficiency in Arabic language learning: Some reflections on basic goals. Arabic methodology reader. Cape Town: UWC.

AL-ATTAS, SMN. 1985. Islam, secularisation and the philosophy of the future. London: Mansell Publishing.

AL-ATTAS, SMN. 1993 (1978). Islam and secularization. $2^{\text {nd }}$ ed. Kuala Lumpur:ISTAC.

BOWKER, J. 1995. Voices of Islam. Oxford: Oneworld.

DADOO, Y. 1990. Approaches to teaching Arabic at South African universities. Perspectives on Islamic Education. Johannesburg: Muslim World League: 81-84.

DAWOOD, I, AMOD, I \& I KADER. 1996. Arabic subject committee workshop. Kwa-Zulu Natal AMS Regional committee. Durban: Lockhat Islamia College.

EBRAHIM, N AND RC JAMAL. 1984. Teaching Arabic - thematic approach. Workshop on Teaching Arabic, held at the Orient Islamic School, Durban.

EBRAHIM, N. 1986. The communicative approach to teaching Arabic. Workshop on the communicative approach to teaching Arabic, held at the Orient Islamic School, Durban.

EMERICK, Y. 2002. The purpose of Arabic language studies. Islamic Foundation of North America. http://www.islamicedfoundation.com/the.htm (accessed 16 July 2002).

EMERICK, Y. 2002. How should Arabic language be taught? Islamic Foundation of North America. http://www.islamicedfoundation.com/arabic/newpage1.htm (accessed 16 July 2002).

KATHRADA, NE. 1985. Teaching Arabic and Islamic history. Orientation course for Madrassa teachers. Stanger Madressa School, Natal. 
MAJID, AJ. 1987. Guidelines for constructing an Arabic curriculum. Unpublished MEd dissertation. Johannesburg: RAU.

MALL, MA. 2001. Teaching of Arabic to learners in Muslim private schools in South Africa and Botswana. Unpublished MEd dissertation. Pretoria: Unisa.

MOHAMED, Y. (ed.). 1997. The teaching of Arabic in South Africa: History and methodology. Bellville: University of Western Cape.

MUJAHID, AM. 2002. Quranic Arabic crisis in Muslim Schools: An urgent appeal. Soundvision.com. http://www.soundvision.com/Info/education/edu.qurarabic.asp (accessed 18 July 2002).

NURUDDIN, S. 1992. Central issues in Arabic teaching. Boorhanul Islam Newsletter, 27(3): 39-43.

THOMAS, AL. 1987. Language teacher competence and language teacher education. In: Bowers, R. (ed.). Language teacher education: an integrated programme for ELT teacher training. Oxford: The British Council.

WESSELS, M AND R VAN DEN BERG. 1998. Practical guide to facilitating language learning: methods, activities and techniques for OBE. Johannesburg: Thomson.

YOUNES, MA. 1990. An integrated approach to teaching Arabic as a foreign language. $\mathrm{Al}$ 'Arabiyya 23: 105-122.

\section{Biographic Note}

MA Mall is the Deputy Principal, Al-Nur School, Gaborone, Botswana \& Ms MM Nieman lectures in the Department of Educational Studies, PO Box 392, Unisa, 0003. Please address all correspondence to Ms MM Nieman. (e-mail: niemamm@unisa.ac.za $<$ mailto:niemamm@unisa.ac.za $>$ ) 